\title{
RUSSIA AND LATIN AMERICA: PROBLEMS AND PROSPECTIVE OF COOPERATION
}

\author{
Z. Zinnatullina ${ }^{*}, 1$, T. Drobysheva ${ }^{2}$ \\ ${ }^{1}$ Kazan Federal University \\ ${ }^{2}$ Saint Petersburg State University
}

Published online: 15 February 2017

\begin{abstract}
The article reveals the continental orientation of the geopolitics of Latin America. It shows the features of development of the Russian Far East. This region remains a promising area, but in Russian current political strategy it occupies a special place. And there is a hope for the Far Eastern region becoming a Russian Federation's power center in the Asia-Pacific region. It is emphasized that nowadays the interests of Latin American countries and Russia coincide in several important areas. We can infer that currently it is a conducive situation for the development of relations between Russia and States in Latin America, especially in the economic sphere and in the sphere of tourism, cultural and educational exchanges. The Far East plays an important role in the development of inter-State relations between Russia and Latin America.
\end{abstract}

Key words: geopolitics, geopolitical vector, geopolitical potential, regional integration, the Far East, Latin America, the Asia-Pacific region, the development of infrastructure.

\section{INTRODUCTION}

It is well known that the modern system of international relations is a multi-polar system. Traditional and new actors in world politics act from the position of their own interests, often without consulting the other participants. Therefore, the leading states, as the traditional subjects of international relations, should create economic, social, political and cultural dialogue with the most promising regions for the cooperative interaction taking into account

Author Correspondence, e-mail: author@gmail.com

doi: http://dx.doi.org/10.4314/jfas.v8i2s.635 
an increasingly complex situation in the modern world.

Because of the recent events on the international arena, such as the war brewing in the Middle East, persisting ethnic conflicts in the former Soviet Union, the heightened threat of terrorism, the question of relations between states and the role of each one in the international arena is particularly acute.

Due to objective factors, including the shift of economic centers of power, social conflicts and others, the world is now at the turn of the epochs. Russia, China, Brazil are ones of the few states looking to review contemporary international relations.

\section{MATERIALS AND METHODS}

Currently, all great prospects could be seen in the growing cooperation between the Russian Federation and Latin America. On the one hand, Latin America has long been on the periphery of the developed world, as a kind of "donor" of manpower and material resources. On the other hand, the Russian Federation in terms of sanctions is interested in finding new partners for the multisphere cooperation and support on the international arena. Therefore, Russia and the Latin American region have great prospects to build long-term and durable partnerships that are extremely important and beneficial for both sides.

The Russian Federation has a significant amount of land resources, and this fact provides a basis for the emergence of promising ideas for development of remote regions. One of the most striking examples of policy on the development of areas is the Far Eastern Federal District. So, the Federal Law "On the territories of advancing social and economic development in the Russian Federation", adopted in 2014, which defines "the legal regime of territories of advanced social and economic development in the Russian Federation, measures of state support and procedure of carrying out activities in such territories", is aimed, primarily, at the development of the Far East. And in accordance with the Presidential Decree "On structure of Federal enforcement authorities" the Ministry for Development of the Russian Far East was established.

The issue of the development of Russia's relations with the Latin America countries and the Caribbean states is also considered by political experts. One example is the international forum "Russia and Ibero-America in a globalizing world: history and modernity", held in October 2015 for the second time in the School of International relations of St. Petersburg State University. However, there is not a lot of notable activities, that's why this event is seen as unique and important. 
Nowadays Brazil, Argentina, Mexico, among other things, develop high-tech production. And the Russian politicians are interested in the developing partnerships in this sphere, it provides new opportunities for Russian investment. Russia is actively expanding its visa-free zone mostly account of the Latin America countries. Latin America becomes a partner in the field of people contacts, touristic and economic exchanges.

As for the education, it is necessary to note the particular importance of linguistics for this field. Currently Spanish, along with English, is widely used in international communication, and Russia can not stay out of this process. Russians know a lot about Spain, its culture and traditions, largely due to world-known figures of Spanish culture such as El Greco, Francisco Goya, Salvador Dali, Pablo Picasso (artists), Miguel de Cervantes (writer), Pedro Calderon (playwright), Federico Garcia Lorca (poet). Spanish gets more and more popular in Russia every day. It becomes the language of tourism and travel. Interest to Spanish, including to learning of its Latin American dialects, is mostly stimulated by the fact that Russia is actively developing relations with Latin America. In September 2015, the head of the Russian Foreign Ministry held meetings with the Foreign Ministers of Brazil, Venezuela, Cuba, Mexico. The most important results were the conclusion of a treaty on the grounds of relations with Haiti and Suriname, and also the visa-waiver treaties with Guyana. The head of the Russian Foreign Ministry Sergey Lavrov appreciated Latin American countries' support of the Russian people in modern conditions and said: "We are not counting on someone's support. [...] We want the world to rely on the consensus of development centers, including Latin America, the Eurasian continent, the Russian Federation, and also the rules developed after the Second World War and enshrined in the UN Charter, were respected and observed by all countries."

The Latin American region today is an area, which drew attention of the whole international community. Actors of international relations understand that the quality of relations with Latin American countries is important to the stability of their position on the international arena. However Latin America nowadays is not an object to struggle, because Latin American countries are not ready to experience external influence, except the influence of one of the countries of the region. And today, this "locomotive of integration" is Brazil. Its economic and political potential makes it the regional leader.

And in the modern realities it is not a coincidence that this region was chosen to host the historical meeting of the heads of the Russian Orthodox Church and the Roman Catholic Church. Speaking of Latin America His Holiness Patriarch Kirill of Moscow and All Russia said: "There are two regions, Russia and Latin America, with which you can associate the 
hope for the revival of Christianity." And his position suggests that current expectations associated with the Latin American region exist not only in political and scientific circles.

On the way to a more productive cooperation in trade and investment spheres, Russia and Latin American countries encounter many obstacles. Russia is not practically involved in the realization of projects in energy, metals, infrastructure sectors. The activities of intergovernmental commissions on economic, scientific and technical cooperation is minimized. This situation impacts negatively upon economic relations in general. Also there is no strong treaty basis for building the solid bilateral relationships.

However, the vectors of interest of the considered actors (Russia and Latin America) coincide in a number of spheres, such as education and culture; oil production and processing (drilling rigs); heavy machinery (machines, etc.); infrastructure; creation of "smart cities"; chemical industry; information and communication technologies; space; energy.

\section{RESULTS}

At present, researchers identify the following main points that form the point of contact between Russia and the Latin American region:

- Russia and Latin American countries are proponents of a multipolar world and an active cooperation within the UN, BRICS, The Group of Twenty;

- Russia and the countries of this region are willing to take a more worthy place in the global geopolitical and geo-economic space, excluding any external interference;

- Russia and Latin American countries are not geo-economic and geo-political rivals, and even, complementary to each other.

\section{DISCUSSION}

Due to the political contradictions between the European Union and the Russian Federation and imposed economic sanctions, bilateral trade between Russia and the EU has decreased. As a result, Latin American countries are the promising area for attraction of Russian investments, mainly in the sphere of innovations. Thus, today, the projects of the National Oil Consortium have been implemented with the foreign participating countries such as Brazil, Argentina, Venezuela, Guyana and Cuba. There are also a number of initiatives to create the scientific associations, which could be an impetus for the development of high technologies in the Latin American region. As a result, this would allow diversify Russian exports. 
We have to pay attention to the linkage between the energy sector and the sphere of education and culture. It is necessary to consider separately the question of the sphere of hydropower and nuclear power, as Latin American countries (including Chile, Peru, Brazil), first of all, have a need of new sources of energy, and secondly, in the training of highly qualified professionals in these areas.

The Russian Federation has the advanced system of training specialist personnel for the energy sector. For example, there is a lot of successful institutions of higher education in the Far Eastern Federal District, including Far Eastern Federal University, Sakhalin State University (and their branches). Furthermore, the big corporations ("Power Machines", "Rosgidro" and others) are the largest investors of the energy sector in the Far East. These companies have developed material and technical base and act as the main practiceoriented areas for improving professional competencies.

The Russian Far East of is very important in geopolitical and economic terms. The Far Eastern Federal District occupies approximately 35\% of the country and therefore it is necessary to develop it. This region is promising not only because of its geographical position, but also because of the significant reserves of natural resources. But today it is very difficult to realize its potential because of the region's poor infrastructure, depopulation, remoteness to the political and economic center of the state. That is despite the fact that the government invests a large amount of resources from the federal budget.

In the current situation on the international political arena Russia seeks to strengthen its position in the Asia-Pacific region. And to achieve this goal it is necessary to implement the plan of the Far East's economically prosperous. The region has the number of advantages, which make this plan is quite feasible. The Far East is the most closely to the growing Asian markets Russian region. Besides its territory has a promising land for farming, as well as huge deposits of hydrocarbon resources, wood and metals.

These resources allow create unique economic cluster in this region that are potentially attractive for investments, including foreign ones. However, in the present situation created by restrictions on the Russian capital in the world market, investing in the economy of the Far East would be an attractive and promising alternative.

But even with these advantages, the federal center of the Russian Federation, has to make significant efforts and pour great investment into the regional infrastructure, especially in energy and transport sectors, to stimulate the flow of capital through the development of business in the region. It is very important for reaching the ultimate goal that is to increase the attractiveness of the Far East and to encourage the population flow into the 
region. Thus, the example of energy and education systems shows us the existence of mutual interest for building partnership relations between Russia and Latin American countries. Today, the cooperation project between Russia and Latin American countries is invited Plenipotentiary Representative of the Russian President in the Far Eastern Federal District.

Substantial assistance in the Russian-Latin American relations development may have the networking with the part of the Latin American population, whose fate has always been connected with Russia: Russian emigrants and their descendants, Latin American graduates of Soviet and Russian universities. Many representatives of these communities are members of the Latin American elite public and influence their countries' strategies. At the same time, now representatives from both parties have been talking widely about the involvement of Russian experts to participate in the Argentine, Brazilian, Venezuelan and Chilean projects. And this will be also a positive influence on the strengthening of the Russian-Latin American communications.

However, despite the above advantages and prospects of this cooperation, there is a number of problems. One of the main obstacles for the development of a long-term cooperation is the increased integration in Latin America. Now the Common Market of the Southern Cone bloc has reached the volume of block GDP, which is comparable with the powerful Asian economic bloc ASEAN.

Also, today there is no alternative transport infrastructure to the normal movement of people across the Pacific Ocean. Accordingly, the inhabitants of the Latin America region see the way to Russia exclusively through the Atlantic Ocean, which is closer to the economic and political center of Russia. That's why it is difficult to attract the attention of foreigners to the Far East. But we can suggest a few ways to make the Far East more attractive. First of all, it is necessary to create such centers in the region that would become useful not only for investment and other cooperation in the economic sphere, but also for tourism, cultural and educational exchanges. In this case Khabarovsk and Vladivostok have an important role to play. The Russian leadership is actively implementing this strategy, which confirmed by the adopted in 2015 federal law "On the free port of Vladivostok", which has among its objectives "the using of geographical and economic advantages of the Primorsky Territory as the Eastern sea gate of the Russian Federation for the integration of the economic space of the Asia-Pacific countries region."

The development of a lasting cooperation, including in the areas described above, is not possible without the submission of nations cooperating with each other. Today it is necessary to create a unified image of the Latin America and Latinos in minds of Russian 
people. For that Russians need to be better informed about this region and its people. In September 2014 the Russian Council on International Affairs organized a "round table" on "Russia and the Pacific Alliance: the possibility of expanding cooperation." During the discussion, participants discussed one of the most important aspects of bilateral cooperation participation of representatives of civil society in the Russian-Latin American dialogue. Former Ambassador of the Russian Federation in Mexico Vladimir Morozov said: "In contrast to, for example, the European Union countries, the representatives of Russian nongovernmental organizations (NGOs) very occasionally visit Latin America and practically do not participate in the discussions on the cooperation expansion between our country and the countries of LAC."

\section{CONCLUSIONS}

Currently, both Russian and foreign researchers pays much attention to the problems of the economic development of the Russian Far East. They research the possibility of the region's development and the establishment of inter-regional relations. The government of the Far East seeks out new relations that could help to strengthen the region. China and Latin American countries are ones of the most important. However, the strategy of China's "peaceful rise" alarms the international community, and the Russian Federation is not an exception. Today, therefore, a lot of hopes are connected with Latin America.

Today one of the main tasks of the Russian Federation should be not only the strengthening of economic ties, successful investing and creation of a favorable climate in the country to attract foreign partners, but also the establishment of strong international relations, which would include a dialogue of cultures, "people's diplomacy", promoted cultural exchanges and the implementation of Russia's policy of "soft power" in the world and in particular in the Latin American region.

\section{REFERENCES}

1. The Federal Law "On the territories of advancing social and economic development in the Russian Federation". - URL: http://www.consultant.ru/document/cons_doc_LAW_172962/(accessed: 04/01/2016)

2. The Presidential Decree "On structure of Federal enforcement authorities". - URL: http://www.consultant.ru/document/cons_doc_law_129954/(accessed: 04/02/2016)

3. The Answers of Minister of Foreign affairs of Russia Sergei Lavrov on the questions of broadcasting company "Teleresurs", Moscow, April,16, 2015. - URL: 
http://www.mid.ru/maps/hn/-/asset_publisher/Q98A8VqvoQKk/content/id/1179347 (access date: 04/01/2016)

4. Patriarch Kirill: "Latin America is almost Russia". - URL: http://www.vesti.ru/doc.html?id=2723084 (accessed: 03/30/2016)

5. Nuryshev G. Russia and Latin America in the modern world. // Zhurnal'nyyklubIntelros “CredoNew”. -2015, №2: URL: http://www.intelros.ru/readroom/credo_new/kr22015/27738-rossiya-i-latinskaya-amerika-v-sovremennom-mire.html (accessed: 28/03/2016).

6. Federal law "On the free port of Vladivostok". - URL: http://docs.cntd.ru/document/420287139 (accessed: 04/04/2016)

7. Russia and the Latin America: prospects for cooperation expansion. URL:http://www.soc-ecologia.ru/2014/10/россия-л тинск я- мерик -перспекти/ (accessed: 04/04/2016)

\section{How to cite this article:}

Zinnatullina Z, Drobysheva T. Russia and latin america: Problems and prospective of cooperation. J. Fundam. Appl. Sci., 2017, 9(1S), 12-19. 